\title{
Female Flight Students: Perceptions of Barriers and Gender Biases within Collegiate Flight Programs
}

\author{
Chad L. Depperschmidt and Timm J. Bliss
}

Oklahoma State University

\begin{abstract}
The purpose of this study was to determine the existence and extent of barriers and gender biases that propagate the under representation of females in collegiate aviation programs. Focusing on female flight students' personal perceptions of their collegiate aviation programs, four research questions were formulated and the findings were supported by using descriptive statistics. This study found: female flight students believed that the under representation of female flight students should be a primary concern for their collegiate aviation program; female flight students do not believe that negative remarks or biases due to gender exist within their collegiate flight program; female flight students do not believe there is a sufficient number of female professionals employed at their collegiate flight program; and that female flight students do believe that both scholarships and internships specifically offered for female flight students are adequately available from their collegiate flight programs. Women have remained underutilized and underrepresented as professional pilots in the United States air carrier industry. If the trend of under representation of females in collegiate flight programs remains unchanged, women will continue to account for a decreased role within the aviation industry.
\end{abstract}

\section{INTRODUCTION}

Historically, the aviation industry has been dominated by males. While the percentage of females in aviation has continually risen over time, they do not constitute a significant representation within the industry. The percentage of active women airmen certificates compared to men has only increased 0.45 percent over the last ten years (Federal Aviation Administration - Table 1, 2008; Federal Aviation Administration - Table 2, 2008). Women only constitute approximately 6 percent of FAA certificated pilots (Women in Aviation International, 2000). Furthermore, the number of female commercial pilots with an airline transport rating in the United States has remained at 3 percent during the past decade, 1996-2006 (Women in Aviation International, 2006).

While females only constitute a small percentage of commercial pilots, they comprise a large resource pool for the commercial aviation industry in the United States (Turney, Karp, Bishop, et al., 2002). Therefore, the commercial aviation industry can significantly increase the amount of females seeking aviation careers if this trend of under representation can be reversed. Providing this opportunity will not only increase the number of females seeking aviation careers, but will enrich the overall talent pool for the commercial air transportation industry.

The under representation of female pilots is an important issue that the aviation industry needs to research and study. A starting point for research on the under representation of female pilots includes the collegiate flight programs where future pilots are typically introduced to the aviation industry. Since the collegiate flight program is the beginning of the journey for many pilot careers, any lessons that may be learned from the knowledge regarding the under representation of women in collegiate flight programs can perhaps be applied to help to solve the same issues throughout the industry. If collegiate flight programs have the capability to improve enrollment and retention rates of female flight students, this can have a ripple effect throughout the industry and will help increase the involvement of women pilots throughout the commercial aviation industry in the United States.

\section{RESEARCH METHODOLOGY}

Guided by descriptive methodology, this 2007 study used a research instrument authored by the researchers. The instrument was administered nationally to 4-year public and private universities and 2-year public and private 
colleges offering comprehensive aviation curriculums, awarding either associate or bachelor degrees in aviation disciplines. Exploratory in nature, this study was designed to elicit information and perceptions related to the under representation of female flight students in collegiate aviation programs in the United States and act as a springboard for further related research.

The objective of the research instrument was to answer the following research questions:

1. Do female flight students believe the under representation of females should be a concern for their collegiate aviation program?

2. Do female flight students believe negative remarks and or biases due to gender exist in their collegiate aviation program? If so, do barriers and gender biases affect female retention within their collegiate aviation program?

3. Do female flight students believe their collegiate aviation program employs a sufficient number of female professionals (faculty, flight school administration, Certified Flight Instructors)?

4. Do female flight students believe academic incentives (scholarships and internships) specific to females are adequate within their collegiate aviation program?

\section{DESCRIPTION OF RESEARCH INSTRUMENT}

The research instrument for this study was created to explore the perceptions of female flight students and identify demographic information related to themselves and their flight program. To ensure the highest level of quality, a pretest of the research instrument was given to eight professionals; representing eight different educational institutions within the field of collegiate aviation. These aviation professionals examined the research instrument to measure its focus related to the research topic and reviewed its clarity of instructions. The final design of the research instrument was modified by the researchers based on responses from this pretest group.
The research instrument was a structured questionnaire consisting of three parts: demographic information, Likert-scale interpretive questions, and personal comment section. The first part of the instrument requested demographic information (yes/no and multiple choice questions) related to the female flight student completing the survey, as well as their collegiate flight program. The second part offered Likert-scale questions with ordinal measurement pattern options ranging from: (1) Strongly Agree, (2) Agree, (3) Disagree, and (4) Strongly Disagree. These questions were intended to gain insight into the perceptions of the female flight student related to their collegiate flight program experiences. The final section of the research instrument consisted of a text box offering the female participants an opportunity to provide personal comments they believed would be appropriate to this study.

\section{SELECTION OF THE RESEARCH POPULATION}

The population for this study was drawn from female aviation students participating in collegiate flight training. The collegiate flight programs solicited for this study were institutional members of the University Aviation Association (UAA) and represent both 2-year and 4-year collegiate flight programs geographically distributed across the United States. Sixty collegiate flight programs were identified as potential participants. Collegiate flight programs for this study were obtained from a 2006 UAA membership list. Only those collegiate flight programs offering comprehensive aviation curriculums; and awarding either associate or bachelor degrees in aviation disciplines were selected by the researchers to participate in this research study.

\section{RESULTS}

Thirty of the sixty identified collegiate flight programs elected to participate in this study. From these thirty participating flight schools, 262 female flight students completed the research instrument. As shown in Figure 1, the thirty participating schools represent a uniform geographic distribution within the United States. 


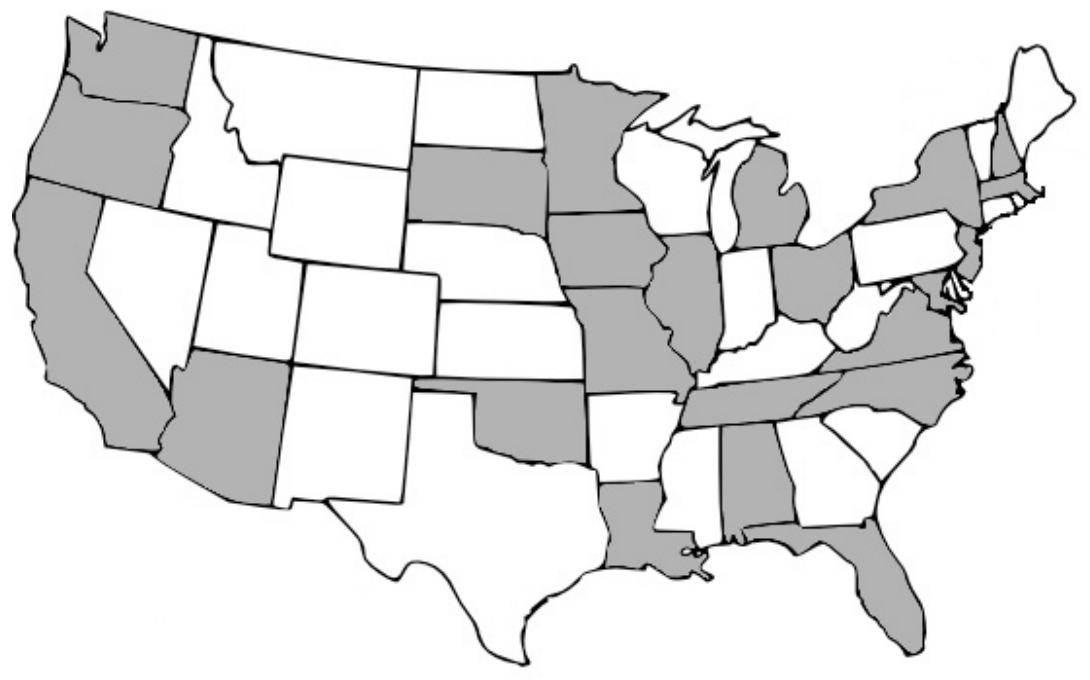

Figure 1. Geographic Distribution of Participating Collegiate Flight Programs. Note: Shaded areas represent states of participating institutions.

Of the thirty collegiate flight programs that participated in the study, there were eighteen 4year public and private institutions (60 percent) and twelve 2-year public and private institutions (40 percent).

Each participating female flight student was asked to identify their academic classification. Table 1 indicates that of the 262 female respondents; 25 percent were freshman, 27 percent were sophomores, 21 percent were juniors, and 27 percent of females were seniors. Factors that influenced the female flight student to major in collegiate aviation were also solicited in this study. Fifty percent of the female flight students indicated no individual specifically influenced them to pursue flight training; it had always been a childhood dream. Only 20 percent of the students indicated they were influenced by their parent(s). Perhaps the reason for this low percentage is that only 17 percent of the female students stated their parent(s) were employed in the aviation industry.

Table 1. Academic Classification of Female Flight Students

\begin{tabular}{|c|c|c|}
\hline $\begin{array}{c}\text { Academic } \\
\text { Classification }\end{array}$ & $\begin{array}{c}\text { Number of } \\
\text { Respondents }\end{array}$ & $\begin{array}{c}\text { Percentage of } \\
\text { Respondents }\end{array}$ \\
\hline Freshman & 65 & $25 \%$ \\
\hline Sophomore & 70 & $27 \%$ \\
\hline Junior & 56 & $21 \%$ \\
\hline Senior & 71 & $27 \%$ \\
\hline
\end{tabular}

In Table 2, full-time student enrollments were separated into five sub groups: 1-50; 51100; 101-150; 151-200; and over 200. Forty-one percent of the female participants indicated their collegiate flight programs have full-time enrollments of less than 100 total students (male and female). The remaining students (59 percent) stated their flight programs have enrollments over 100 full-time students.

Table 2. Full-Time Flight Students (Male \& Female) Enrolled in Collegiate Flight Program

\begin{tabular}{|c|c|c|}
\hline $\begin{array}{c}\text { Full-Time } \\
\text { Students } \\
\text { Enrolled }\end{array}$ & Responses & $\begin{array}{c}\text { Percentage of } \\
\text { Responses }\end{array}$ \\
\hline $1-50$ & 44 & $17 \%$ \\
\hline $51-100$ & 61 & $24 \%$ \\
\hline $101-150$ & 56 & $22 \%$ \\
\hline $151-200$ & 60 & $23 \%$ \\
\hline Over 200 & 36 & $14 \%$ \\
\hline
\end{tabular}

Table 3 indicates the percentage of female full-time flight students enrolled in their respective collegiate flight program. When compared to the estimation of total (male and female) full-time flight students, female flight students represented a very small percentage of overall flight students. An overwhelming 98 percent of participating female students indicated that full-time female flight students accounted for less than 25 percent of total student enrollments in their collegiate flight 
program. Seventy percent of these females indicated that full-time females enrolled in their collegiate flight programs accounted for only 010 percent of total full-time flight students.

Table 3. Percentage of Female Full-Time Flight Students Enrolled

\begin{tabular}{c|c|c}
$\begin{array}{c}\text { Percentage Full- } \\
\text { Time Female } \\
\text { Students } \\
\text { Enrolled }\end{array}$ & Responses & $\begin{array}{c}\text { Percentage of } \\
\text { Responses }\end{array}$ \\
\hline \hline $0-10 \%$ & 181 & $70 \%$ \\
$11-25 \%$ & 76 & $28 \%$ \\
$26-50 \%$ & 1 & $1 \%$ \\
Over 50\% & 1 & $1 \%$
\end{tabular}

The female flight students' current flight certificate or rating is presented in Table 4. A higher number of responses, 279 , were received from the female flight students because many of them were pursuing multiple certificates or ratings. The three most common flight certificate or ratings indicated were Private Pilot (24 percent), Commercial (25 percent), and Instrument (24 percent). Those who chose the option of other had the opportunity to identify their current flight certificate or rating; all responded Airline Transport Pilot (ATP).

Table 4. Pursuant Flight Certificate/ Rating

\begin{tabular}{|c|c|c|}
\hline $\begin{array}{c}\text { Flight Certificate/ } \\
\text { Rating }\end{array}$ & Responses & $\begin{array}{c}\text { Percentage } \\
\text { of } \\
\text { Responses }\end{array}$ \\
\hline Private Pilot & 66 & $24 \%$ \\
\hline Commercial & 69 & $25 \%$ \\
\hline Instrument & 67 & $24 \%$ \\
\hline Multi-Engine & 27 & $10 \%$ \\
\hline $\begin{array}{c}\text { Multi-Engine } \\
\text { (Instrument) }\end{array}$ & 10 & $3 \%$ \\
\hline $\begin{array}{c}\text { Certified Flight } \\
\text { Instructor }\end{array}$ & 27 & $10 \%$ \\
\hline $\begin{array}{c}\text { Certified Flight } \\
\text { Instructor } \\
\text { (Instrument) }\end{array}$ & 7 & $2 \%$ \\
\hline Other & 6 & $2 \%$ \\
\hline
\end{tabular}

To understand the influence of female mentorship at each collegiate flight program, the survey asked flight students to identify the amount of employed female flight instructors and female flight administrators (Director,
Manager, and Chief Flight Instructor). Table 5 indicates the percentage of employed female flight instructors employed in the respondents' collegiate flight program. An overwhelming 75 percent of respondents indicated their flight school only employed 0-5 female flight instructors. Of these respondents, eighteen percent indicated there were no female flight instructors employed at their flight school. And yet, one responding student thought there were adequate female flight instructors, commenting; "My flight program generally does an excellent job in hiring female flight instructors/professors. Because numbers lean towards men, they try to match female students with female CFI's."

Table 5. Representation of Female Certified Flight Instructors Employed at Female Flight Students' Collegiate Flight Program

\begin{tabular}{|c|c|c|}
\hline $\begin{array}{c}\text { Number of } \\
\text { Female Flight } \\
\text { Instructors } \\
\text { Employed }\end{array}$ & Responses & $\begin{array}{c}\text { Percentage of } \\
\text { Responses }\end{array}$ \\
\hline 0 & 46 & $18 \%$ \\
\hline $1-5$ & 148 & $57 \%$ \\
\hline $6-10$ & 46 & $18 \%$ \\
\hline $11-20$ & 14 & $5 \%$ \\
\hline Over 20 & 7 & $2 \%$ \\
\hline
\end{tabular}

As indicated in Table 6, only a small percentage of surveyed collegiate flight programs had a female administrator. Only twenty respondents (8 percent) indicated their collegiate flight program had a female administrator, while 240 respondents (92 percent) did not have a female administrating their collegiate flight school. One of the students believed female leaders within her collegiate flight program was important, by commenting; "More female professors and instructors would definitely help in motivating other females to pursue a career in the aviation field."

Table 6. Representation of Female Management at Collegiate Flight Schools

\begin{tabular}{|c|c|c|}
\hline $\begin{array}{c}\text { Female } \\
\text { Administrator }\end{array}$ & Responses & $\begin{array}{c}\text { Percentage of } \\
\text { Responses }\end{array}$ \\
\hline Yes & 20 & $8 \%$ \\
\hline No & 240 & $92 \%$ \\
\hline
\end{tabular}

Table 7, Female Flight Students' Financial Sources for Flight Costs, presents the financial 
source for funding the respondents' flight costs. The majority of the female flight students indicated multiple financial sources resulting in 355 total responses. Among the five survey choices, respondents indicated their primary financial source for flight costs: (1) parent(s), 33 percent; (2) school loans, 34 percent; (3) scholarships, 18 percent; (4) myself, 9 percent; and (5) other, 6 percent. The female students who chose the other option were asked to identify the funding source. Included in the choices were: retirement, spouse, Air Force ROTC, and Veterans grant. Over one-half, 52 percent, of the female students' responses indicated that school loans and scholarships were the primary financial sources for their flight costs.

Table 7. Female Flight Students’ Financial Sources for Flight Costs

\begin{tabular}{|c|c|c|}
\hline $\begin{array}{c}\text { Financial } \\
\text { Source }\end{array}$ & Responses & $\begin{array}{c}\text { Percentage of } \\
\text { Responses }\end{array}$ \\
\hline Parent(s) & 118 & $33 \%$ \\
\hline School Loans & 121 & $34 \%$ \\
\hline Scholarships & 63 & $18 \%$ \\
\hline Myself & 32 & $9 \%$ \\
\hline Other & 21 & $6 \%$ \\
\hline
\end{tabular}

Likert-type statements that examine the female flight student's perceptions regarding the concern of their flight school to recruit and retain female flight students are presented in Table 8. Approximately one-half of the female respondents (55 percent) strongly agreed or agreed, compared with 45 percent that disagreed or strongly disagreed with the statement: The under represented number of female flight students should be a primary concern of the aviation department at my institution. Similar percentages were indicated when the student's were asked their perceptions of the following statement: My aviation department/institution does an excellent job of recruiting females students to my collegiate flight program. Fiftysix percent of the female students strongly agreed or agreed, while 44 percent either disagreed or strongly disagreed with this statement. One female stated; “Although there are not many female aviation students, I believe my school has done its best to recruit females and offers us the same opportunity as male students.”

Table 8. Female Flight Students' Perception of Institutional Recruitment and Retaining of Female Flight Students

\begin{tabular}{lc|c|c|c}
\multicolumn{1}{c|}{ Likert-Type Statements } & SA & A & D & SD \\
\hline \hline The under represented number of female flight students should & 59 & 83 & 105 & 13 \\
be a primary concern of the aviation department at my & $23 \%$ & $32 \%$ & $40 \%$ & $5 \%$ \\
institution. & & & & \\
My aviation department/institution does an excellent job of & 20 & 126 & 100 & 14 \\
recruiting females students to my collegiate flight program. & $8 \%$ & $48 \%$ & $39 \%$ & $5 \%$ \\
My aviation department/institution makes efforts to attract & & & & \\
more young females (junior high and high school) to careers & 17 & 121 & 102 & 18 \\
in aviation through educational opportunities and public & $7 \%$ & $47 \%$ & $39 \%$ & $7 \%$ \\
outreach. & & & & \\
$\begin{array}{l}\text { There are a sufficient number of professional females (faculty, } \\
\text { flight school personnel, CFIs) in my collegiate flight program. }\end{array}$ & $6 \%$ & $43 \%$ & $41 \%$ & $10 \%$
\end{tabular}

Over half of respondents (54 percent) either strongly agreed or agreed with the statement: $M y$ aviation department/institution makes efforts to attract more young females (junior high and high school) to careers in aviation through educational opportunities and public outreach.
The remaining 46 percent either disagreed or strongly disagreed with the statement. One female student actually wrote on her survey, "My aviation department has not made any effort to attract more young females to careers in 
aviation through educational opportunities and public outreach. It's as if they don't care."

Approximately half of the female flight students (51 percent) indicated they disagreed or strongly disagreed opposed to 49 percent that agreed or strongly agreed with the statement: There are a sufficient number of professional females (faculty, flight school personnel, CFIs) in my collegiate flight program. One responding female stated; "My flight program generally does an excellent job in hiring female flight instructors/professors." However; in support of the 51 percent of respondents that disagreed with the statement, one of the female students indicated: "I believe that female pilots are under more pressure and feel as if we have to exceed our ability to 'prove' we are just as able as male pilots. I would like to see more women pilots at my flight school as well as CFI's.”

Table 9. Female Flight Students’ Perception of Institutional Financial Barriers and Opportunities

\begin{tabular}{lc|c|c|c}
\multicolumn{1}{c|}{ Likert-Type Statements } & SA & A & D & SD \\
\hline \hline The current cost of flight training at my collegiate flight school has & 14 & 72 & 124 & 50 \\
an affect on the ability of female flight students to pursue an & $5 \%$ & $28 \%$ & $48 \%$ & $19 \%$ \\
aviation career (pilot) at my educational institution. & & & & \\
My aviation department/institution offers sufficient aviation & 37 & 117 & 87 & 18 \\
scholarships to assist female students with their flight costs. & $14 \%$ & $45 \%$ & $34 \%$ & $7 \%$
\end{tabular}

Responding to the Likert-type statement in Table 9, The current cost of flight training at my collegiate flight school has an effect on the ability of female flight student to pursue an aviation career (pilot) at my educational institution, only 33 percent of the female students either agreed or strongly agreed that flight costs have an affect of them pursuing a professional pilot degree at their institution. The majority of females, 67 percent, disagreed or strongly disagreed that institutional flight costs affected their ability to pursue an aviation career.

Almost 60 percent of female flight students agreed or strongly agreed to the statement: $M y$ aviation department/institution offers sufficient aviation scholarships to assist female students with their flight costs. The remaining 41 percent of students disagreed or strongly disagreed with the statement, with one of the flight students stating on her survey; "One major concern of mine is the inadequate number of scholarships offered or made available to female students."

Table 10 lists the perceptions of the female flight student related to the following experiences: (1) favoritism toward male flight students regarding internships, scholarships, or flight instructor positions; (2) rude or offensive remarks targeted at female flight students; (3), existence of gender biases within the flight school, and (4) female flight students quitting flight training due to barriers and/or gender biases.

The majority of female flight students (85 percent) disagreed or strongly disagreed with the statement: Favoritism towards male flight students (internships, scholarships, CFI positions) exists in my collegiate flight program. The remaining 15 percent of female students agreed or strongly agreed that favoritism towards male flight students does actually exist within their flight program.

Eighty-five percent of female flight students disagreed or strongly disagreed while the other 15 percent of female students agreed or strongly agreed with the statement: Negative (rude and offensive) comments regarding female flight students are frequent at my collegiate flight school. While the majority of respondents indicated that negative or rude comments are not frequent, many of the responding female students expressed otherwise. 
Table 10. Female Flight Students' Perception of Gender Barriers, Biases, or Favoritism Against Female Flight Students

\begin{tabular}{lc|c|c|c}
\multicolumn{1}{c|}{ Likert-Type Statements } & SA & A & D & SD \\
\hline \hline Favoritism towards male flight students (internships, & 5 & 34 & 143 & 80 \\
scholarships, CFI positions) exists in my collegiate flight & $2 \%$ & $13 \%$ & $55 \%$ & $30 \%$ \\
program. & & & & \\
Negative (rude and offensive) comments regarding female & 5 & 33 & 114 & 110 \\
flight students are frequent at my collegiate flight school. & $2 \%$ & $13 \%$ & $43 \%$ & $42 \%$ \\
& 6 & 53 & 110 & 93 \\
Gender "biases" exist in my collegiate flight program. & $2 \%$ & $20 \%$ & $42 \%$ & $36 \%$ \\
& 7 & 23 & 134 & 98 \\
The primary reason female flight students quit collegiate & $3 \%$ & $9 \%$ & $51 \%$ & $37 \%$
\end{tabular}

One respondent indicated, "There is a tremendous amount of insults to females that go on at my school in a continuous way." Another student expressed her experiences by stating, "Female students have a hard time because of the ways male students talk. I get offended almost daily but keep going because I want to be in the organizations and on the flight team, but if the guys would clean up their language I think more females would join and stick with it. I know of females that don't get involved because of how the guys treat them and talk around them." Lastly, a third female flight student indicated, "I have encountered many students that discredit my achievements, such as my ability to pass check rides. Comments such as 'just wear a low-cut shirt and you'll pass your check ride' or 'you just passed because you're a girl' are very common.”

Seventy-eight percent of female flight students either disagreed or strongly disagreed, compared to 22 percent who agreed or strongly agreed with the statement: Gender "barriers" exist in my collegiate flight program. Even though the majority of female respondents disagreed with this statement regarding gender barriers, most comments written by the female students related to the existence of gender barriers. One female student wrote,

"At the flight center and on campus I feel that women have to work twice as hard to receive the same amount of recognition as males. I feel like I have to work and study to get ahead of the males so that I have 'evidence' of myself not being considered a 'joke' in the eyes of the management and staff. I've seen cases when I had a legitimate concern about why I was continually being put on standby for an aircraft and instructor, and when they were voiced I was pretty much laughed at and told to go away. When a male asked the same thing, things were changed for him. I had to climb the management ladder to get anything done. It finally worked, but took much longer."

Another respondent stated, "A lot of us girls feel that we need to work twice as hard as the men to get the same recognition. Most of the men are fine but it's the few that are biased and prejudiced that ruins it for others." This sentiment is continued by another female student, "My professors try to be very supportive; other males are for the majority awful towards me, they always assume we are management majors and a huge joke. Rarely taken seriously or respected." Perhaps, barriers and gender biases exist outside of the collegiate flight program as well, as one respondent remarked, "It does bother me when someone asks me what my major is and when I tell them they're always in shock.”

Lastly, the majority of female flight students (88 percent) disagreed or strongly disagreed with the statement: The primary reason female flight students quit collegiate flight programs is because of gender barriers and biases. One student's opinion supports this perception by commenting, "Based on my own 
experience, it seems that much of the reason that many women quit aviation is a lack of confidence. They are comparable to men in skills and general knowledge, but they tend to be less confident in their abilities. Males often jump right into things like solo cross countries whereas females tend to be more worried about the consequences like not finding the airport, getting lost, or violating FAR's.”

\section{CONCLUSIONS}

Women constitute a small percentage of commercial pilots within the aviation industry. Currently, females represent approximately 2 percent of all airline captains in the United States (Guide to College, 2005). This research study sought to identify the existence of barriers or gender biases that contribute to the under representation of female students within collegiate aviation programs. With a better understanding of whether barriers or biases do actually exist within the collegiate flight environment and if they contribute to the under representation of female flight students; then actions can possibly be implemented and applied to encourage more women to seek professional careers as pilots.

Based on the data collected from this study, the majority of female flight students do not believe that negative remarks or biases due to gender exist at their collegiate flight program. Respondents indicated that overall, their collegiate flight program environments were respectful and supportive of female flight students. In support, one female flight student commented, "As a whole, my collegiate flight program, I think, is accepting of female flight students". Another respondent commented, "Overall flight training at my college is fair and equal between male and female students, after all, the airplane does not care what gender you are." Therefore; perhaps, the under representation of female flight students at the collegiate level may be affected by other factors than gender biases or barriers. One female flight student respondent commented, "I have found that the industry is male dominated not because of biases or barriers, but rather because it's just the "'norm"'. I have never been discouraged or looked down upon based on my gender. If anything, I have been encouraged and people are genuinely interested in how to attract more females into the industry." Another respondent indicated that workload and commitment may be factors to this under representation issue. She commented, 'I'm not entirely sure why an aviation career doesn't attract more females. Perhaps it is because of the strain of completing the flight practicum in addition to a classroom workload. Also because there are so many males in the industry, it seems intimidating for women to compete for jobs, even positions in the flight program. It is extremely high pressure and requires commitment."

However, the female respondents did indicate the under representation of female flight students at collegiate aviation programs should be a concern at their collegiate flight programs. Over half (55 percent) of the female students believed their under representation should be a concern for collegiate flight program administration. And yet, fifty-six percent of females indicated their collegiate flight program does an excellent job of recruiting female flight students to their program. While the respondents indicated that collegiate flight programs do a good job of recruiting female flight students, the total number of female flight students in collegiate programs still remains significantly small. Seventy percent of responding females indicated they represent only 0 to 10 percent of total enrolled flight students (male and female) in their collegiate flight program.

Possibly a barrier to this under representation problem, comments from female flight students indicated the need for additional female professionals employed at their collegiate flight programs. Only 8 percent of the females stated the administrator of their collegiate flight program was female; and fifty-one percent of respondents disagreed that there are a sufficient number of female professionals (faculty, flight school personnel, CFI's) at their collegiate flight program. Furthermore, 75 percent of respondents indicated there was only 0 to 5 female certified flight instructors employed at their collegiate aviation program. One respondent commented, "I think that identifying female pilots in the aviation industry plays a big role in motivating other females to pursue a career in the aviation field. More female 
professors and instructors would also definitely help.” Another female flight student commented, "I find our flight schools problem is trying to recruit females to fly here. We are unique because our director and chief pilot are both female. We should be using it as an opportunity to go out into the local community and spread aviation to young girls."

The high cost of flight training can be a significant barrier to completing flight training at collegiate aviation programs. Often a degree in aviation flight can be among the most expensive four year degrees offered by the institution (Aviation College Decision, 2008). When indicating the financial sources for flight costs, the two most common responses were parents and school loans. However, almost 60 percent of responding female flight students believed their collegiate aviation program offers a sufficient amount of aviation scholarships to assist them with their overall flight costs.

While females have increased their representation in aviation throughout time, they still remain under represented. When represented as collegiate flight students, professional pilots within the commercial air carrier industry, and pilot certificate holders; women constitute a very small percentage when compared to males. Continued consideration should be given to the under representation of females within collegiate aviation and the commercial air carrier industry; and the existence of any barriers or gender biases discouraging female involvement in aviation. 


\section{REFERENCES}

Aviation College Decision. (2008). Retrieved April 26, 2008, from http://www.nataaero/about/college decision/jsp

Federal Aviation Administration 2006 U.S. Civil Airmen Statistics (2008). Table 1 Estimated Active Airmen Certificates Held December 31, 1997-2006. Retrieved April 26, 2008, from http://www.faa.gov/data_statistics /aviation_data_statistics/civil_airmen_statistics/2008/

Federal Aviation Administration 2006 U.S. Civil Airmen Statistics (2008). Table 2 Estimated Active Women Airmen Certificates Held December 31, 1997-2006. Retrieved April 26, 2008, from http://www.faa.gov/data_statistics/aviation_data_statistics/civil_airmen_statistics/2006/

Guide to College. (2005). Majors in Aviation Science. Retrieved on April 26, 2008, from http://www.worldwidelearn.com/online-education-guide/ science/aviation-science-major.htm

Turney, Mary Ann., Karp, Merrill R., Bishop, James C., Niemczyk, Mary., Sitler, Ruthe L., \& Green, Mavis F., (2002). An Applied Training Model for Retention of Women in Aviation. The Interservice/Industry Training, Simulation \& Education Conference, 2002, 42-56.

Women in Aviation International. (2006). Current Statistics of Women in Aviation Careers in U.S. Retrieved April 30, 2007, from http://www.wai.org/resources /facts.cfm

Women in Aviation International. (2000). The Facts 2000. [Brochure]. West Alexandria, OH: Author. 